\title{
Appliance of acute phase proteins, cytokines, biogram and hemogram as markers for nanoparticles-induced clinicopathological alterations.
}

\author{
Ibtsam Gheith* \\ Department of Medical Laboratories Technology, Faculty of Applied Medical Sciences, Taibah University, 344 \\ Medinah, Kingdom of Saudi Arabia
}

\begin{abstract}
Objective: The goal of this study is to assess and confirm the clinical importance of measurement of positive and negative acute phase proteins parameters as biomarkers for inflammation; and alterations in blood picture induced by nanoparticles instead of back to tissue biopsy and histopathology.

Methods: Rats were randomly grouped into three groups, $1^{\text {st }}$ group acted as control group and received $1 \mathrm{ml} / \mathrm{d}$ distilled water; the $2^{\text {nd }}$ group received $1 \mathrm{ml}$ of distilled water containing iron oxide at $100 \mu \mathrm{g} / \mathrm{kg}$ concentrations using stomach tube; while the $3^{\text {rd }}$ group received $1 \mathrm{ml}$ of distilled water containing iron oxide at $150 \mu \mathrm{g} / \mathrm{kg}$ concentrations, for a period of 4 weeks. The clinic-pathological effects were observed by estimating the alterations in different functional parameters of the liver in serum using chemical kits and in the hematological parameters by using autohematology analyzer.

Results: Alterations were in the form of significant elevations of AST, ALT and ALP enzyme activities; significant decreases in total and conjugated bilirubin; significant increases in all positive acute phase proteins and decreases in all negative acute phase ones; with significant increases in IL-1 $\alpha$, IL-6 and TNF- $\alpha$ cytokines and a disturbance in lipogram appearing as remarkable high total lipids, cholesterol, LDL-C, VLDL-C, with significant decrease in HDL-C. These results were associated with alterations in hematological parameters and occurrence of anemia in both $2^{\text {nd }}$ and $3^{\text {rd }}$ groups.

Conclusion: Nanoparticles have double-edged sword that ultra-structure of these articles seem to have advantage in the treatment, but in the same time may cause marked injuries to the vital organs as liver and related functions,
\end{abstract}

Keywords: Nanoparticles, Acute phase proteins, Ferritin, C-reactive protein, Hemogram, Biogram, Cytokine. Accepted on March 07, 2018

\section{Introduction}

The use of nanomedicine that applies nanoparticle technology in medicine in recent years has achieved a revolution in the medical and pharmaceutical industry fields. Different pharmaceutical products have been developed using this technology for the treatment of various disease conditions, including cancer.

It should be noted that nanoparticles can enter the body and living tissues via different routes as mentioned by Bockmann et al. including water, food, drugs and cosmetics [1]. Therefore, this type of very tiny particles can enter to the body intentionally or unintentionally as it enters into many formulations and industries that we all use in our daily lives. Some of it has antimicrobial activity, the matter that explains their widespread use in water purification, tooth paste, shampoo and rinses, filters, creams and ointments used in wounds and burns as sliver nanoparticles [2].

Even though, in 2013, data revealed that nanoparticles can disrupt proliferating system in male rats as a model of human by decreasing in testosterone and increasing in $\mathrm{LH}$ hormone concentration. Also, Fartkhooni et al., studied the side effect of nano titanium dioxide $\left(\mathrm{TiO}_{2}\right)$ in spermatogenesis [3]; while experimental results, showed that iron oxide nanoparticles at higher concentrations inhibits the hypothalamus-pituitary axis and thus thyroid gland can cause malfunctions [4]. Upon that, it could be stated that these very tiny particles, therefore, have a two-edged sword, and thus in this sense, this study was prepared.

The main risk of these ultra-particles is attributed to its ability to penetrate all living cell membranes, which may result in accumulation of such particles in the organ causing toxic effects even if the subject appears healthy. Till now, no enough data are available to draw complete picture about the way of releasing nanoparticles out of the cell after its penetration.

It is well established that nanoparticles, because of its smaller size, move freely across the cell membranes and physiological barriers and, thus, have the ability to enter, translocate and generate oxidative stress causing considerable cell/tissue damage [5]. The small particle size also may enable nanoparticles to have cumulative effects; some scientific 
studies have detected significant amounts of silver in the liver of rats following oral administration of silver nanoparticles at escalating doses ranging between $30 \sim 500 \mathrm{mg} / \mathrm{kg} / \mathrm{d}$ for $90 \mathrm{~d}$ [6].

However, till now nanoparticle lethal doses and detailed exact actions on biological systems are not completely known as mentioned by different researchers. Nevertheless, the toxicity of nanoparticles might be attributed to two reasons, the first is the size of the particles and the second is the surface area of the particles [7].

Iron oxide is one of the most famous nanoparticles that many companies have to manufacture in different forms and sizes to utilize it as carriers for drug preparations for target specific drug delivery, as carriers for certain genes in gene therapy and as particular therapeutic agents for hyperthermia-based cancer treatments. In addition, the investigation of the effects of nanoparticles containing iron on blood and compared between it and that of ferrous sulfate in rats suffering from anemia, was concluded that bioavailability of iron nanoparticles was higher than that of ferrous sulfate, which is considered the most common supplement for treatment of anemia with good absorption rate [8]. Based on that important finding, the attention of recent researchers goes toward replacing it after discovering its side effect on bacteria in the colon and its undesirable effect on the colonal epithelium [9].

Assessment of the pro-inflammatory cytokines and different acute phase proteins give indication to the inflammatory status without having to go back to the biopsy from the organs or histopathology. Actually, acute phase proteins may be defined as a group of proteins secreted from the liver after exposure to inflammation or stimulus or infection and used as parameters for assessing inflammation. They are subdivided as positive and negative acute phase parameters associated with its increase and decrease, respectively; while pro-inflammatory cytokines are produced by the innate immune cells as neutrophils, monocytes, $\mathrm{T}$ cells, and macrophages. They secrete different cytokines which rise in the blood and affect many organs as interleukin-1 and interleukin-6 which contribute to the inflammatory response (Figure 1) [10].

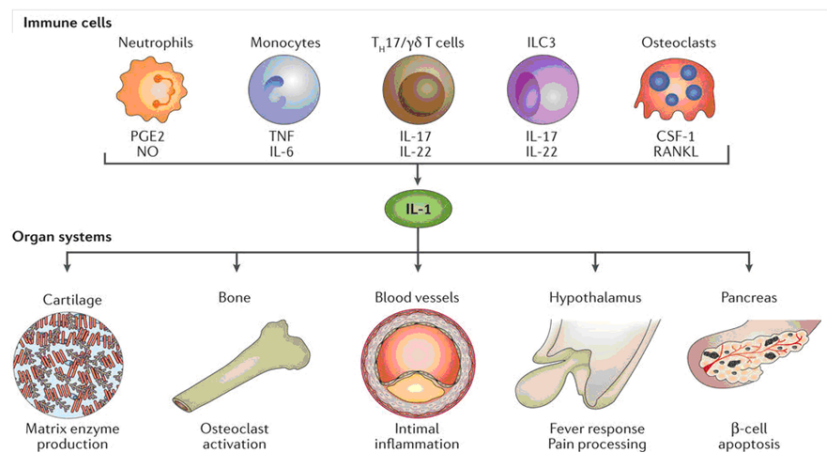

Figure 1. Diagram illustrating the source of interleukins and its function (Schett et al.) [10].

Therefore, the topic of nanoparticles seems to be fascinating for many researchers and scientists. Researchers intensify their efforts to know all the benefits as well as risks of this technology in many different fields and to know more and more about these particles, which was not yet completely understood till now.

In this sense, this study was conducted on rats to know and discuss the clinicopathological impact of the use of this type of ultra-structured particles on the different parameters of the liver, pro-inflammatory cytokines, positive and negative acute phase protein parameters and the possible effect of these alterations, if any, on the hemogram.

\section{Materials and Methods}

\section{Animal husbandry}

After acclimatization period ( 2 weeks), thirty adult male rats weighting from (200-250 gm) were experimented in this study. Rats were housed under conditions of constant temperature, humidity in lab animal cages, and food and fresh drinking water were available ad libitum.

\section{Nanoparticles}

Iron oxide nano-powder $\left(\mathrm{Fe}_{2} \mathrm{O}_{3}\right)$ was purchased from Sigma Aldrich (St. Louis, USA); the product information indicated a particle size of $<100 \mathrm{~nm}$ diameter and a specific surface area of $5 \mathrm{~m}^{2} / \mathrm{g}$.

\section{Experiment design}

The rats were randomly assigned to three groups in a parallel study design. The $1^{\text {st }}$ (control) group included 10 animals, received $1 \mathrm{ml} / \mathrm{d}$ of distilled water; the second group included 10 rats, received $1 \mathrm{ml} / \mathrm{d}$ of distilled water containing iron oxide at $100 \mu \mathrm{g} / \mathrm{kg}$ using stomach tube; while the third group rats (10) received iron oxide nanoparticles at higher dose of 150 $\mu \mathrm{g} / \mathrm{kg}$. Administration was continued to all rats for experimental period of 4 weeks.

\section{Laboratory analysis of different parameters}

At the end of experimental period (4week), a blood sample was taken via retro-orbital venous plexus of the rat eye, as whole blood, in EDTA-containing sample tube for analysis of hematological parameters using automated hematology analyzer $\left(\right.$ Sysmex ${ }^{\circledR}$, USA). Another blood sample was withdrawn in sodium citrate-tube, for determination of erythrocytic sedimentation rate by Westergren method. A third blood sample was withdrawn in plain tubes for separation of serum for estimation of different liver enzymes and acute phase protein parameters (positive and negative) by using different chemical kits.

Liver enzyme activities, including Alanine Aminotransfere (ALT), Aspartate Aminotransferase (AST) and Alkaline Phosphatase enzyme (ALP) were measured according to the methods described by Bergmeyer et al. and Bessey et al. $[11,12]$. Lipid profile parameters, including total lipid, cholesterols (TC), serum HDL-C, triglycerides serum (TAG), were estimated according to the methods described by Chabrol 
Appliance of acute phase proteins, cytokines, biogram and hemogram as markers for nanoparticles-induced clinicopathological alterations

et al., respectively [13-16]. The serum LDL-C and VLDL-C values were calculated by using the following formula:

$\mathrm{LDLC}=\mathrm{TC}-(\mathrm{HDLC}+\mathrm{TAG} / 5) \mathrm{mg} / \mathrm{dL}$

$\mathrm{VLDLC}=\mathrm{TAG} / 5 \mathrm{mg} / \mathrm{dL}$

Estimation of different acute phase protein parameters in the serum was adopted by using a set of chemicals. Total protein was estimated according to Cannon et al., albumin was estimated by using method of Doumas et al. [17,18]; while iron was estimated according to Tietz [19].

Serum ferritin and C-reactive protein levels were determined by ELISA method. And a multiplex biometric ELISA was adopted for determination of IL- $1 \alpha$, IL- 6 , and TNF- $\alpha$ according to methods cited in Iavicoli1 et al. [20].

\section{Statistical analysis}

Data of the present study are expressed as means \pm standard error of the mean. Statistical significance among means was analyzed by one-way ANOVA and Tukey's as a post-hoc test using SPSS, version 16.0. Significance level was set at $\mathrm{p}<0.05$ $[21,22]$.

\section{Results}

Statistical analysis of the data presented in Table 1, showed significant increase in all of the indicators of hepatocyte injury, including, AST, ALT, ALP enzyme activities in samples of the $2^{\text {nd }}$ and the $3^{\text {rd }}$ groups, when compared with those of the control group at the end of experimental period.

Total and direct bilirubins data were analyzed and listed in Table 1, the results showed a significant decrease in total and direct bilirubins in the $2^{\text {nd }}$ and the $3^{\text {rd }}$ group samples, when comparing with those of the $1^{\text {st }}$ group.

Table 1. Biogram of different groups (mean $\pm S E$ ).

\begin{tabular}{|c|c|c|c|c|}
\hline \multirow[b]{2}{*}{ Parameters } & \multirow[b]{2}{*}{$\begin{array}{l}\text { Numbe } \\
r \text { of rat } \\
\text { in each } \\
\text { group }\end{array}$} & \multicolumn{3}{|c|}{ Doses of exposure $(\mu \mathrm{g} / \mathrm{kg})$ and grouping } \\
\hline & & $\begin{array}{l}\text { Group (A) } \\
\text { (distal } \\
\text { water) } 1 \mathrm{ml}\end{array}$ & $\begin{array}{l}\text { Group (B) (iron } \\
\text { oxide } \\
\text { nanoparticles) } \\
100 \mu \mathrm{g} / \mathrm{kg}\end{array}$ & $\begin{array}{l}\text { Group (C) (iron } \\
\text { oxide } \\
\text { nanoparticles) } \\
150 \mu \mathrm{g} / \mathrm{kg}\end{array}$ \\
\hline $\operatorname{ALT}(U / L)$ & 10 & $31.98 \pm 5.50$ & $86.30 \pm 6.73^{*}$ & $102.31 \pm 9.00^{*}$ \\
\hline AST (U/L) & 10 & $18.40 \pm 1.49$ & $86.10 \pm 3.04^{*}$ & $89.00 \pm 3.54^{*}$ \\
\hline ALP (U/L) & 10 & $43.35 \pm 3.69$ & $67.07 \pm 3.38$ & $68.63 \pm 11.43$ \\
\hline $\begin{array}{l}\text { Total bilirubin } \\
(\mathrm{mg} / \mathrm{dl})\end{array}$ & 10 & $1.40 \pm 0.06$ & $0.76 \pm 0.13$ & $0.75 \pm 0.07$ \\
\hline $\begin{array}{l}\text { Conjugated } \\
\text { bilirubin (mg/dl) }\end{array}$ & 10 & $1.16 \pm 0.03$ & $0.56 \pm 0.17$ & $0.20 \pm 0.04$ \\
\hline $\begin{array}{l}\text { Total proteins } \\
(\mathrm{g} / \mathrm{dl})\end{array}$ & 10 & $6.85 \pm 0.54$ & $4.30 \pm 0.55^{*}$ & $3.99 \pm 0.46^{*}$ \\
\hline Albumin (g/dl) & 10 & $3.32 \pm 0.11$ & $3.22 \pm 0.17$ & $1.67 \pm 0.31^{*}$ \\
\hline
\end{tabular}

In Table 2, the results of lipogram in the $2^{\text {nd }}$ and the $3^{\text {rd }}$ groups revealed significant increases in total lipids, total cholesterol, triglyceride, LDL-C, VLDL-C with significant decreases in HDL-C, when compare with those of the control group.

Table 2. Changes in lipogram parameter of different groups (mean \pm $S E)$.

\begin{tabular}{|c|c|c|c|c|}
\hline \multirow[b]{2}{*}{ Parameters } & \multicolumn{4}{|c|}{ Doses of exposure $(\mu \mathrm{g} / \mathrm{kg})$ and grouping } \\
\hline & $\begin{array}{l}r \text { of rat } \\
\text { in each } \\
\text { group }\end{array}$ & $\begin{array}{l}\text { Group }(A) \\
\text { (distal water) } \\
1 \mathrm{ml}\end{array}$ & $\begin{array}{l}\text { Group (B) (iron } \\
\text { oxide } \\
\text { nanoparticles) } \\
100 \mu \mathrm{g} / \mathrm{kg}\end{array}$ & $\begin{array}{l}\text { Group (C) (iron } \\
\text { oxide } \\
\text { nanoparticles) } \\
150 \mu \mathrm{g} / \mathrm{kg}\end{array}$ \\
\hline $\begin{array}{l}\text { Total } \\
(\mathrm{mg} / \mathrm{dl})\end{array}$ & 10 & $\begin{array}{l}348.92 \\
13.13\end{array}$ & $469.08 \pm 33.30^{*}$ & $623.51 \pm 34.30^{*}$ \\
\hline $\begin{array}{l}\text { Total } \\
\text { cholesterol } \\
(\mathrm{mg} / \mathrm{dl})\end{array}$ & 10 & $62.91 \pm 7.48$ & $153.96 \pm 8.03^{*}$ & $176.03 \pm 2.96^{*}$ \\
\hline $\begin{array}{l}\text { Triacylglycerols } \\
(\mathrm{mg} / \mathrm{dl})\end{array}$ & 10 & $77.87 \pm 6.54$ & $159.00 \pm 2.45^{*}$ & $186.00 \pm 3.10^{*}$ \\
\hline $\begin{array}{l}\text { Serum } \\
(\mathrm{mg} / \mathrm{dl})\end{array}$ & 10 & $39.78 \pm 0.58$ & $17.58 \pm 0.87^{*}$ & $15.97 \pm 0.76^{*}$ \\
\hline $\begin{array}{l}\text { Serum } \\
\text { (mg/dl) }\end{array}$ & 10 & $22.67 \pm 5.62$ & $109.41 \pm 15.11^{*}$ & $131.94 \pm 12.1^{*}$ \\
\hline $\begin{array}{l}\text { Serum VLDLC } \\
(\mathrm{mg} / \mathrm{dl})\end{array}$ & 10 & $15.40 \pm 1.38$ & $31.80 \pm 0.49^{*}$ & $37.19 \pm 0.62^{*}$ \\
\hline
\end{tabular}

*Significantly different from (A).

Assessment of inflammation markers, including acute phase proteins is shown in Table 3, where the data revealed increases of all positive acute phase proteins (Ferritin, TIBC, Ceruloplasmin and CRP) associated with significant decrease in the negative ones (total serum iron, total proteins, albumin, transferring saturation $\%$ ) in the $2^{\text {nd }}$ and the $3^{\text {rd }}$ group when compared with those of the first group.

Table 3. Changes in different acute phase parameter (mean $\pm S E$ ).

\begin{tabular}{|c|c|c|c|c|}
\hline \multirow[b]{2}{*}{ Parameters } & \multirow[b]{2}{*}{$\begin{array}{l}\text { Numbe } \\
r \text { of rat } \\
\text { in each } \\
\text { group }\end{array}$} & \multicolumn{3}{|c|}{ Doses of exposure $(\mu \mathrm{g} / \mathrm{kg})$ and grouping } \\
\hline & & $\begin{array}{l}\text { Group }(\mathrm{A}) \\
\text { (distal water) } \\
1 \mathrm{ml}\end{array}$ & $\begin{array}{l}\text { Group (B) (iron } \\
\text { oxide } \\
\text { nanoparticles) } \\
100 \mu \mathrm{g} / \mathrm{kg}\end{array}$ & $\begin{array}{l}\text { Group (C) (iron } \\
\text { oxide } \\
\text { nanoparticles) } \\
150 \mu \mathrm{g} / \mathrm{kg}\end{array}$ \\
\hline $\begin{array}{l}\text { Total serum iron } \\
(\mu \mathrm{g} / \mathrm{dl})\end{array}$ & 10 & $255.40 \pm 6.52$ & $207.34 \pm 5.98^{*}$ & $172.02 \pm 11.22^{*}$ \\
\hline TIBC $(\mu \mathrm{g} / \mathrm{dl})$ & 10 & $\begin{array}{l}164.20 \\
11.97\end{array}$ & $229.44 \pm 12.96$ & $283.19 \pm 39.35^{*}$ \\
\hline $\begin{array}{l}\text { Transferrin } \\
\text { saturation (\%) }\end{array}$ & 10 & $75.49 \pm 3.30$ & $45.26 \pm 2.87^{*}$ & $33.64 \pm 1.56^{*}$ \\
\hline Ferritin $(\mu \mathrm{g} / \mathrm{dl})$ & 10 & $\begin{array}{l}137.05 \\
32.70\end{array}$ & $229.25 \pm 15.91^{*}$ & $273.29 \pm 10.63^{*}$ \\
\hline $\begin{array}{l}\text { Ceruloplasmin } \\
(\mathrm{mg} / \mathrm{dl})\end{array}$ & 10 & $6.22 \pm 0.54$ & $11.04 \pm 0.37^{*}$ & $12.30 \pm 0.50^{*}$ \\
\hline CRP (mg/l) & 10 & $\begin{array}{l}114.70 \\
22.30\end{array}$ & $211.05 \pm 22.15$ & $292.07 \pm 292.07^{*}$ \\
\hline
\end{tabular}


"Significantly different from (A).

For confirming the results of acute phase parameters, the cytokines quantitative alterations were assessed and presented in Table 4. IL-1 $\alpha$ data showed significant increase $\left(2^{\text {nd }}\right.$ and $3^{\text {rd }}$ groups), while the results of IL- 6 and TNF- $\alpha$ showed significant increase ( $3^{\text {rd }}$ group only), when compared with the data of the $1^{\text {st }}$ group.
As for the hematological parameters, as shown in Table 5, remarkable significant decreases in the RBCS count, HB concentration, $\mathrm{PCV} \%$, with remarkable increase in total WBCS count were detected in the $2^{\text {nd }}$ and $3^{\text {rd }}$ groups, when comparing with the control one. Moreover, a significant increase in the ESR in the $1^{\text {st }} \mathrm{h}$ of sedimentation as indirect index of inflammation was observed, at the end of the experimental period.

Table 4. Alteration in different cytokines (mean $\pm S E$ ).

\begin{tabular}{|c|c|c|c|c|}
\hline \multirow[b]{2}{*}{ Parameters } & \multirow{2}{*}{$\begin{array}{l}\text { Number of rat in } \\
\text { each group }\end{array}$} & \multicolumn{3}{|c|}{ Doses of exposure $(\mu \mathrm{g} / \mathrm{kg})$ and grouping } \\
\hline & & $\begin{array}{l}\text { Group (A) (distal water) } 1 \\
\mathrm{ml}\end{array}$ & $\begin{array}{l}\text { Group (B) (iron oxide nanoparticles) } \\
100 \mu \mathrm{g} / \mathrm{kg}\end{array}$ & $\begin{array}{l}\text { Group (C) (iron oxide nanoparticles) } \\
150 \mu \mathrm{g} / \mathrm{kg}\end{array}$ \\
\hline IL-1a (pg/ml) & 10 & $254.92 \pm 3.12$ & $320.54 \pm 6.91^{*}$ & $303.14 \pm 4.86^{*}$ \\
\hline IL-6 (pg/ml) & 10 & $226.56 \pm 13.44$ & $261.46 \pm 16.57$ & $285.52 \pm 7.30^{*}$ \\
\hline TNF- $\alpha(p g / m l)$ & 10 & $204.91 \pm 8.98$ & $230.00 \pm 11.2$ & $254.54 \pm 18.00^{*}$ \\
\hline
\end{tabular}

*Significantly different from $(A)$.

Table 5. Hemogram of different groups (mean $\pm S E)$.

\begin{tabular}{|c|c|c|c|c|}
\hline \multirow{2}{*}{ Parameters } & \multirow{2}{*}{$\begin{array}{l}\text { Number of rat } \\
\text { in each group }\end{array}$} & \multicolumn{3}{|c|}{ Doses of exposure $(\mu \mathrm{g} / \mathrm{kg})$ and grouping } \\
\hline & & $\begin{array}{l}\text { Group (A) (distal water) } 1 \\
\text { ml }\end{array}$ & $\begin{array}{l}\text { Group (B) (iron oxide nanoparticles) } 100 \\
\mu \mathrm{g} / \mathrm{kg}\end{array}$ & $\begin{array}{l}\text { Group (C) (iron oxide nanoparticles) } \\
150 \mu \mathrm{g} / \mathrm{kg}\end{array}$ \\
\hline $\mathrm{RBCS} \times 10^{12} / \mathrm{L}$ & 10 & $4.34 \pm 0.45$ & $3.20 \pm 0.10^{*}$ & $3.81 \pm 0.26^{*}$ \\
\hline $\mathrm{Hb}(\mathrm{g} / \mathrm{dl})$ & 10 & $15.63 \pm 0.76$ & $13.00 \pm 0.87$ & $11.96 \pm 0.76^{*}$ \\
\hline PCV (\%) & 10 & $35.95 \pm 0.29$ & $30.66 \pm 0.97^{*}$ & $28.69 \pm 0.42^{*}$ \\
\hline $\operatorname{ESR}(\mathrm{mm})\left(1^{\mathrm{st}} \mathrm{h}\right)$ & 10 & $1.33 \pm 0.33$ & $2.60 \pm 0.33^{*}$ & $4.66 \pm 0.33^{*}$ \\
\hline WBCS $\times 10^{9} / \mathrm{L}$ & 10 & $7.47 \pm 0.29$ & $9.39 \pm 0.27^{*}$ & $9.69 \pm 0.15^{*}$ \\
\hline
\end{tabular}

\section{Discussion}

Metabolism of proteins, lipids and carbohydrates; protein synthesis; detoxification; storage of glycogen; destroying of the old red blood cells and breakdown of hemoglobin; modulating oncotic pressure and blood pressure by synthesis of different substances; breakdown of bilirubin via glucuronidation and facilitation of its excretion into bile; and maintaining normal glucose level in the body by converting the stored sugar to functional sugar when the body's glucose levels fall below normal; are among the vital roles mediated by the liver.

Vital processes in the body and hemogram are surely affected by any alteration in liver function or hepatocyte inflammation. This might occur after its penetration by ultra-structured particles, which have the ability to penetrate the cell membrane and, thus, affect most of cell organelles.

Results of AST, ALT and ALP enzymes mentioned in Table 1 revealed significant increase in their activities. Theses enzymes act as the main biomarkers of injures of hepatocyte, and helping in diagnosis of healthy status of the liver, and in monitoring the hepatic function improvement during therapy. Results of the present study indicate occurrence of hepatic inflammation by the two doses of iron oxide nanoparticles. These results may be in harmony with Babadi et al., who concluded the occurrence of hepatocyte damage and appreciated elevation in liver enzymes after iron oxide nanoparticles [23].

Most bilirubin is produced during the breakdown of hemoglobin and other hemoproteins. Hypobilirubinemia and the decline of conjugated bilirubin recorded in this study (Table 1) may indicate reduction in the rate of bilirubin conjugation in the liver by Uridine Diphosphate (UDP)glucuronyl transferase. This decline in conjugation rate may be attributed to the hepatocellular damage which decrease hepatocellular ability of conjugation, and to the decline in the concentration of albumin (as mentioned in following results) which act as carrier for unconjugated bilirubin to the liver for conjugation. The result of bilirubin may agree with those reported by Magaye et al. [24]. 
Remarkable alterations of lipogram are listed in Table 2. These alterations included significant increases in total lipids, cholesterol, triglyceride, LDL-C, VLDL-C in the iron nanoparticle-treated groups, associated with significant decrease in HDL-C. These results added more support to those previously reported by Magaye et al. who mentioned an increase in cholesterol in rats after nanoparticle injection [24].

The decline of good healthy cholesterol (HDL-C) and increment of bad unhealthy cholesterol (LDL-C), may give a warning to the atheroscolosis and other cardiovascular disease.

The results of Table 3 indicate significant increase in positive acute phase proteins, including, Ferritin, TIBC, ceruloplasmin and CRP, with significant decrease in the total serum iron, total proteins, albumin and transferring saturation (\%). The aforementioned results confirmed that all the positive acute phase proteins were in direct relation with the increase of the stimulus, inflammation. However, the negative acute phase proteins were inversely proportional to the stimulus and inflammation intensity.

The elevation in TIBC concentration may be as a result of decrement in iron concentration that is because high iron binding capacity levels typically account for low levels of iron in the blood. After such findings, the decline in UIBC was logic and expected.

Ferritin is one among positive acute phase proteins as mentioned by Beck et al., which increases during the inflammation and stress [25]. Yet, it may increase without altering of iron concentration in the body, and thus its increment cannot compensate the anemia condition. The results revealed increase in the concentration of ferritin in both groups treated with iron oxide nanoparticles at the end of experimental indicating inflammation.

The significant increment of C-Reactive Protein (CRP) results in the $2^{\text {nd }}$ and the $3^{\text {rd }}$ groups indicate and confirm the inflammation occurred, as CRP is one of positive acute phase proteins that increases following secretion of pro-inflammatory cytokines from macrophages and T-cells. C-reactive protein has been categorized as the recommended marker for monitoring cardiovascular disease and risk; moreover, being a clearer predictor for atherosclerosis than other markers, including plasma LDL level. It is now established that as an acute-phase parameter, elevation of CRP may mediate signaling pathways in atherosclerosis process as mentioned by Paul et al. and its elevation comes hand with hand with the alteration in LDL and gives indication and picture about healthy status of the arteries and heart [26].

The measurement of transferrin saturation (\%) can be done by calculation using a formula requiring two data (serum iron level and serum total iron binding capacity level) reported by Voyvoda et al. [27,28]. The formula states that transferrin saturation $(\%)=($ Total iron $/$ TIBC $) \times 100$; this equation means that transferrin saturation $(\%)$ is directly proportional to the total serum iron, and inversely proportional to TIBC, and so the decline in total serum iron and elevation TIBC is accompanied with a decrease in the transferrin saturation (\%)
(Table 4). This finding indicates that this parameter acts as a negative acute phase protein. Again, the decline of the transferrin saturation (\%) may be attributed to the hepatocyte dysfunction because hepatocyte is the main source of transferrin.

The results in Table 1 may indicate significant hypoproteinemia, hypoalbuminemia in the $2^{\text {nd }}$ and $3^{\text {rd }}$ groups. This decline was as a result of hepatocyte injury as the liver is the main site of protein synthesis. This may confirm the stressful inflammatory condition form which rat suffers after continued receiving iron nanoparticle, which was confirmed after elevation of positive acute parameter, and decline in different negative acute proteins parameters. This stress condition, logically, may decline the rate of the absorption capacity of intestinal villi of all nutrients especially protein.

As for ceruloplasmin, the data of Table 3 show significant increase in the $2^{\text {nd }}$ and $3^{\text {rd }}$ groups. This result might be attributed to the tissue injuries accompanied by iron oxide administration. This result may support the result of Al-Saadi et al. who reported that tissue injury is usually accompanied by the elevation of plasma ceruloplasmin concentration [24].

More conformation of alteration of different acute phase protein parameters can be drawn from data listed in Table 4. The data show remarkable increases in different cytokines, in the $2^{\text {nd }}$ and $3^{\text {rd }}$ groups. This result may be in harmony with those of Iavicoli et al., who concluded that administration of nanoparticle induced a significant increase of different cytokines as IL-1 $\alpha$, IL- 4, IL-6, IL-10, IL-12, GM-CSF and INF- $\gamma$ [20]. Not only quantitative measurement of these cytokines, but also Khan et al., reported a transient increase in IL-1 $\beta$, IL- 6 and TNF- $\alpha$ gene expressions in rat livers exposed to gold nanoparticles by using qRT-PCR and different primer sequences used for real-time PCR amplifications for different pro-inflammatory cytokines $[29,30]$.

In general, the measurement of different acute phase parameters is useful in monitoring the health status and act as biomarker of inflammation rather than the cytokine measurements, and the reason due to the different cytokines are removed from the blood circulation within a few hours, whereas acute phase protein levels following a single stimulus may still observed for $48 \mathrm{~h}$ or later [31]. Moreover, after analyzing all the data of the $2^{\text {nd }}$ and the $3^{\text {rd }}$ groups as shown, the inflammation occurring as a result of using of nanoparticles iron oxide was confirmed, with no need to either biopsy or histopathology. That is because all of the recorded results confirmed the occurrence of inflammation; and in addition, confirmed the ability of nanoparticles to modulate and alter all biomarkers of inflammation.

After alteration of different biochemical parameters secreted from the liver, especially the falling down of serum iron and increasing of TIBC, occurrence of anemia was expected. This expectation was confirmed by the alteration in the hematological parameters and indices listed in Table 5. The data showed significant decreases in the total RBCS count, $\mathrm{PCV} \%$ and hemoglobin concentration in the $2^{\text {nd }}$ and the $3^{\text {rd }}$ 
groups at the end of experimental period. This decline indicates the occurrence of anemia, which was in accordance with the result obtained by Gaharwar et al. [32]. Nanoparticles could cause anemia by two ways; the first one is indirect by affecting iron concentration which is a main component of hemoglobin; also ferritin, which is the storage form of iron in the body and is elevated as a result of inflammation, however, cannot compensate anemia. The $2^{\text {nd }}$ anaemic way of nanoparticles on RBCS is direct by enhancing oxidative stress and reduction of cellular antioxidants, that the author stated that free radical stressors generated by nanoparticles may act as the main tool for destroying RBCs [32]. In addition, the radicals may result in release of malonyl-di-aldehyde (an indication of lipid peroxidation). Our results are also in line with a previous study that revealed that magnetite nanoparticles were found to induce lipid peroxidation at concentration of $20 \mu \mathrm{g} / \mathrm{ml}$ in lung's epithelial cells and human bone marrow mesenchymal stromal cells (hBMSCs) [33]. Similar results have been recorded in a previous study where mice were exposed to $\mathrm{TiO}_{2}$ NPs [34]. Yet, further studies are needed to know the effect of nanoparticles on the stem cells, bone marrow and other hematopoietic tissues.

Moreover, the observed significant leukocyosis in samples taken from the rats of the $2^{\text {nd }}$ and the $3^{\text {rd }}$ groups may be related to that nanoparticles induce an inflammatory response, as supported by all previous mentioned results, with logic increase in the activity of the immune system [35]. These results are in the same line of Gaharwar, who mentioned an increase in the WBCs (as monocytes and neutrophils) [32]. However, the results are not in the same line of those of Cheraghi et al., who reported falling of leukocyte number after nanoparticle application [36].

ESR elevation in the $2^{\text {nd }}$ and the $3^{\text {rd }}$ groups might be related also to inflammation of liver. The ESR is among the targeted measurements of acute phase response and is considered as indirect index of stress for inflammation or infection because its elevation may occur as a result of elevation of fibrinogen concentration. It helps detecting inflammation and anemia [37]. It is well-established that anemia is one of the factors that is associated with increment of ESR. Increased ESR value might also follow changes in protein/fibrinogen concentrations associated with altered fibrinogen: globulin ratio which enhances "Rouleaux formation" occurring during sedimentation process [38].

The above result confirmed the occurrence of inflammation and confirmed the release of pro-inflammatory cytokines in the blood and its role in affecting the liver to secrete different inflammatory markers and alteration of acute phase protein parameters, which give indication to the inflammatory status of the body and alarm occurrence of inflammation without need to pathological sections or biopsies from organs.

\section{Conclusion}

This study concluded two important statements; the first one is that nanoparticles have double-edged sword that ultra-structure of these articles seem to be have advantage in the treatment, but in the same time may cause marked injuries to the vital organs as liver and related functions, thus, it can induce inflammation to different degrees in the organs associated with elevation/decline in different markers. The $2^{\text {nd }}$ statement is that a researcher can confirm the occurrence of inflammation with subsequent anemia via measurement of different acute phase protein parameters, and monitor progress of inflammation therapy without back to a biopsy or histopathology. However, further experimental investigations are necessary to get better and final conclusion concerning safety of nanoparticles on all vital organs as brain, spinal cord and bone marrow.

\section{Conflict of Interest}

The author states no conflict of interest.

\section{Acknowledgement}

The author is grateful to Prof. Dr. AbuBakr El-Mahmoudy for proofreading.

\section{References}

1. Bockmann J, Lahl H, Eckert T, Unterhalt B. Blood titanium levels before and after oral administration titanium dioxide. Pharmazie 2000; 55: 140-143.

2. Chen J, Han CM, Lin XW, Tang ZJ, Su SJ. Effect of silver nanoparticle dressing on second degree burn wound. Zhonghua Wai Ke Za Zhi 2006; 44: 50-52.

3. Fartkhooni FM, Noori A, Momayez M, Sadeghi L, Shirani $\mathrm{K}$, Babadi, VY. The effects of nano titanium dioxide (TiO2) in spermatogenesis in wistar rat. Euro J Exp Biol 2013; 3: 145-149.

4. Shirband A, Najafi L, Babadi, VU, Zarji MEB, Najafi A, Mirzakhani F, Najafi S, Golzadeh J, Amraie E. Effect of iron oxide nanoparticles on thyroid hormones in rats. Elixir Appl Chem 2013; 56: 13883-13885.

5. Li N, Sioutas C, Cho A, Schmitz D, Misra C, Sempf J, Wang M, Oberley $T$, Froines J, Nel A. Ultrafine particulate pollutants induce oxidative stress and mitochondrial damage. Environ Health Perspect 2003; 111: 455-460.

6. Kim YS, Song MY, Park JD, Song KS, Ryu HR, Chung YH, Kyung CH, Lee Ji H, Oh KH, Kelman BJ, Hwang IK, Yu IJ. Subchronic oral toxicity of silver nanoparticles. Part Fibre Toxicol 2010; 7: 20.

7. Cha K, Hong HW, Choi YG, Lee MJ, Park JH, Chae HK, Ryu G, Myung H. Comparison of acute responses of mice livers to short-term exposure to nano-sized or micro-sized silver particles. Biotechnol Lett 2010; 30: 1893-1899.

8. Shafie EH, Keshavarz SA, Kefayati ME, Taheri F, Sarbakhsh P, Vafa MR. The effects of nanoparticles containing iron on blood and inflammatory markers in comparison to ferrous sulfate in anemic rats. Int J Prev Med 2016; 7: 117.

9. Werner T, Wagner SJ, Martínez I, Walter J, Chang JS, Clavel T, Kisling S, Schuemann K, Haller D. Depletion 
of luminal iron alters the gut microbiota and prevents Crohn's disease-like ileitis. Gut 2011; 60: 325-333.

10. Schett G, Dayer JM, Manger, B. Interleukin-1 function and role in rheumatic disease. Nat Rev Rheumatol 2016; 12: 14-24.

11. Bergmeyer HU, Horder M, Rej R. International Federation of Clinical Chemistry (IFCC) Scientific Committee. Analytical section: approved recommendation (1985) on IFCC methods for the measurement of catalytic concentration of enzymes. Part 2. IFCC method for aspartate aminotransferase (L-aspartate: 2-oxoglutarate aminotransferase, EC 2.6.1.1). J Clin Chem Clin Biochem 1986; 24: 497-510.

12. Bessey OA, Lowry OH, Brock, MJ. A method for the rapid determination of alkaline phosphates with five cubic millimeters of serum. J Biol Chem 1946; 164: 321-329.

13. Chabrol E, Castellano ASPV. Method for estimation of total serum lipid. J Laboratory Clin Med 1961; 57: 300.

14. Meiattini F. The 4-hydroxybenzoate/4-aminophenazone chromogenic system. Clin Chem 1978; 24: 2161-2165.

15. Friedewald WT, Levy RI, Fredrickson DS. Estimation of the concentration of lowdensity lipoprotein cholesterol in plasma without use of the ultracentrifuge. Clin Chem 1972; 18: 449-502.

16. Young D, Pestaner L. Effects of disease on clinical laboratory tests. Clin Chem 1975; 21: 5.

17. Cannon DC, Olitzky I, Inkpen JA. Proteins. In: Clinical chemistry, principles and technics (2nd ed). Harper \& Row, New York 1974; 407-421.

18. Doumas BT, Walson WA, Biggs HG. Albumin standard and the measurement of serum albumin with bromocresol green. Clin Chem Acta 1971; 31: 87-96.

19. Tietz NW. Fundamentals of clinical chemistry (2nd ed). Clin Chem 1994; 692.

20. Iavicoli I, Fontana L, Corbi M, Leso V, Marinaccio A, Leopold K, Schindl R, Sgambato A. Exposure to palladium nanoparticles affects serum levels of cytokines in female wistar rats. Plos One 2015; 5: 1-15.

21. Tekindal MA, Uysal UC, Dolgun MO. Examining public purchases in the medical field with multiple correspondence analysis. Biomed Res 2016: 366-370.

22. Tekindal MA, Güllü Ö, Yazıcı AC, Yavuz Y. The cochranarmitage test to estimate the sample size for trend of proportions for biological data. Turk J Field Crops 2016; 21: 286-297.

23. Babadi VY. Evaluation of iron oxide nanoparticles effects on tissue and enzymes of liver in rats. J Pharm Biomed Sci 2012; 23: 1-4.

24. Magaye RR, Yue X, Zou B, Shi H, Yu H, Liu K, Lin X, Xu $\mathrm{J}$, Yang $\mathrm{C}$, $\mathrm{Wu} \mathrm{A}$, Zhao J. Acute toxicity of nickel nanoparticles in rats after intravenous injection. Int $\mathrm{J}$ Nanomed 2014; 9: 1393-1402.

25. Beck G, Ellis TW, Habicht GS, Schluter SF, Marchalonis JJ. Evolution of the acute phase response: iron release by echinoderm (Asterias forbesi) coelomocytes, and cloning of an echinoderm ferritin molecule. Dev Comp Immunol 2002; 26: 11-26.

26. Paul A, Kery W, Lan Li, Yechoor V, McCrory M, Szalai A, Chan L. C-reactive protein accelerates the progression of atherosclerosis in apolipoprotein E-deficient mice. Circulation 2004; 109: 647-655.

27. Voyvoda H, SeÇkin S, Bıldık A. Koyunlarda Dexamethason uygulamasının serum demir, total demir bağlama kapasitesi, transferrin doyumu ve bakır düzeyine etkisi. VAN Veterinary J 1992; 3: 197-208.

28. Gheith IM, Ozbak HA, Hemeg HA, El-Mahmoudy AM. Modulation of acute phase parameters of inflammation by probiotics in albino rats. Euro J Inflamm 2015; 13: 91-100.

29. Al-Saadi NH, Al-Naqib MK, Ali ZH. Investigated of ceruloplasmin activity and related elements, copper and zinc in patients with colon cancer. Int J Curr Eng Technol 2014; 14: 2112-2115.

30. Khan HA, Abdelhalim MA, Alhomida AS, Al Ayed MS. Transient increase in IL-1 $\beta$, IL-6 and TNF- $\alpha$ gene expression in rat liver exposed to gold nanoparticles. Genet Mol Res 2013; 12: 5851-5857.

31. Gruys E, Toussaint MJM, Niewold TA, Koopmans SJ. Acute phase reaction and acute phase proteins. J Zhejiang Univ Sci 2005; 11: 1045-1056.

32. Gaharwar US, Paulraj R. Iron oxide nanoparticles induced oxidative damage in peripheral blood cells of rat. Biomed Sci Eng 2015; 8: 274-286.

33. Novotna B, Jendelova $\mathrm{P}$, Kapcalova $\mathrm{M}$, Rossner $\mathrm{P}$ Jr, Turnovcova K, Bagryantseva Y, Babic M, Horak D, Sykova E. Oxidative damage to biological macromolecules in human bone marrow mesenchymal stromal cells labeled with various types of iron oxide nanoparticles. Toxicol Lett 2012; 210: 53-63.

34. Duan Y, Liu J, Ma L, Li N, Liu H, Wang J, Zheng L, Liu C, Wang X, Zhao X, Yan J, Wang S, Wang H, Zhang X, Hong F. Toxicological characteristics of nanoparticulate anatase titanium dioxide in mice. Biomaterials 2010; 31: 894-899.

35. Hauck TS, Anderson RE, Fischer HC, Newbigging S, Chan WC. In vivo quantum-dot toxicity assessment. Small 2010; 6: 138-144.

36. Cheraghi J, Hosseini E, Hoshmandfar R, Sahraei R. Hematologic parameters study of male and female rats administrated with different concentrations of Silver Nanoparticles. Int J Agriculture Crop Sci 2014; 7: 700-707.

37. Raymond OP, Michael FG. De Swiet's Medical disorders in obstetric practice (5th edition). Blackwell Publishing Ltd, UK 2010.

38. Imoru M, Emeribe AO. Haemorrheological profiles in apparently healthy pregnant women in Calaba, Nigeria. Afr J Bio 2008; 7: 4354-4358.

\section{*Correspondence to}

Ibtsam Gheith

Department of Medical Laboratories Technology 
Faculty of Applied Medical Sciences

Taibah University

344 Medinah

Kingdom of Saudi Arabia 